\title{
Um Tempo Para Jogar: 0 'Ser Brasileiro' na Publicidade da Copa do Mundo de 1998
}

Édison L uis Gastaldo

Este trabalho consiste em uma versão condensada de alguns aspectos abordados em minha tese de doutoramento, desenvolvida no Programa de Pós-Graduação em Multimeios da UNICAMP, sob orientação do Prof. Dr. Etienne Samain (Gastaldo 2000). Dedico aqui uma particular ênfase aos aspectos metodológicos da pesquisa que resultou nesta tese. Considero necessária tal ênfase visando a contribuir com o desenvolvimento do campo das pesquisas em Antropologia da Comunicação. De modo particular, procuro também adensar uma visão antropológica a respeito da publicidade, entendida como um locus privilegiado de produção de representações sociais. Ao produzir e reproduzir determinadas representações sobre a sociedade, o discurso publicitário contribui para o estabelecimento de consenso social sobre determinados significados e, por esta via, colabora na construção da hegemonia de determinados grupos sobre a sociedade. Assim, entendo a publicidade como uma modalidade discursiva específica, que possui um grande potencial ideológico, e que, como produtora/ reprodutora de aspectos do imaginário social, constitui-se em um rico campo de investigações para uma Antropologia da Comunicação.

No caso específico deste trabalho, minha pesquisa abordou as representações envolvendo o 'ser brasileiro' nos anúncios publicitários veiculados durante o período da Copa do Mundo de 1998. Busquei estabelecer o cruzamento teórico de dois eixos básicos: a participação do futebol como fato social constituinte da identidade brasileira, e a retórica da imagem publicitária, considerada como produtora de um universo simbólico de representações sociais. A partir do cruzamento desses dois eixos, pesquisei, nas imagens Campos 1:123-146, 2001. 
brasileiro', e os processos segundo os quais uma identidade nacional é representada pelo discurso publicitário.

\section{FUTEBOL E CULTURA BRASILEIRA}

Um importante aspecto constituinte da cultura brasileira contemporânea é a apropriação social do futebol como fato cultural. O esporte chamado de football association (no Brasil, simplesmente 'futebol') desde os anos 50 tem servido como um importante demarcador de diferença na relação dos 'brasileiros' com os 'estrangeiros'. Trazido para o Brasil no início do século por funcionários de empresas inglesas, sua prática esteve no princípio associada às elites, juntamente com o remo, outro esporte em voga na época². Uma espécie de 'mito de origem' do futebol no Brasil, aceito quase unanimemente, atribui a entrada deste esporte no Brasil a Charles Miller, brasileiro filho de ingleses que, voltando da Inglaterra, presumivelmente em 1894, trouxe em sua bagagem as regras, dois jogos de uniformes e duas bolas de couro ${ }^{3}$. Paulatinamente, foi se popularizando, e em poucas décadas já era um esporte de massas, com intensa participação das camadas populares, tanto dentro como fora de campo.

Ao futebol jogado no Brasil são atribuídas características constituintes do que seria uma 'identidade brasileira', como a modalidade de conduta conhecida como 'malandragem'. Embora historicamente datados do início do processo de industrialização da sociedade brasileira, nos anos 30 e 40, os tempos da 'malandragem' constituem uma espécie de 'passado mítico' da cultura brasileira, sendo a figura do malandro uma espécie de 'herói popular' brasileiro. Oliven (1986:34) considera a malandragem uma "estratégia de sobrevivência e concepção de mundo", através de uma recusa da disciplina (e da exploração) do trabalho assalariado. Embora o contexto histórico e social contemporâneo tenha relegado o 'malandro' (de navalha, terno branco e lenço de seda no pescoço) ao passado, sua figura emblemática continua presente no imaginário da sociedade brasileira. Um dos campos onde a 'malandragem' é vista essencialmente como um valor no Brasil é justamente o campo de futebol, palco de ritualizações de diversos elementos da cultura brasileira. Neste sentido, Soares (1994:68) relaciona futebol e malandragem no Brasil, considerando a malandragem um "mito constituidor da identidade brasileira", definindo-a como uma "orientação 
maneira própria dos brasileiros de praticarem este esporte, numa modalidade que ele chama de "futebol-malandro". Embora a relação estabelecida por este autor entre as categorias 'futebolforça" e "futebol-arte" com os pensamentos políticos de tipo "totalitário" e "liberal" seja interessante, sua análise é muito centrada nos aspectos pragmáticos do jogo, em entrevistas com jogadores de futebol profissionais, evitando interpretações dos aspectos simbólicos presentes no universo deste esporte. Soares nota com muita propriedade que os atributos que, segundo seus entrevistados, caracterizam o "ser malandro" em um jogo de futebol, como o equilíbrio psicológico, a inteligência e a experiência, são valorizados em todas as atividades esportivas, não se constituindo, em si, nenhum princípio diferenciador (portanto constituidor de identidade). Entretanto, a constituição social de uma identidade passa justamente pela reinterpretação destes atributos, que serão dotados de sentido a partir de uma "lógica simbólica" (que o autor evita interpretar) do grupo, que deve ser decodificada.

A construção social de um modo brasileiro de jogar futebol é afirmada também por Roberto Da Matta (1982), que considera que uma mesma atividade pode ser apropriada de formas diferentes por diferentes sociedades, como é o caso do futebol no Brasil, diferente do futebol praticado nos países europeus, por exemplo. Ele ressalta que, no Brasil, o futebol é sempre chamado "jogo", o mesmo termo que classifica os chamados "jogos de azar", como o também brasileiro "jogo-dobicho"5. Na Inglaterra, em comparação, existe uma distinção clara entre sport e gamble, limites que, no Brasil, são muito mais tênues. Para Da Matta, o futebol no Brasil é uma espécie de "drama da vida social", onde se colocam em cena questões estruturais e hierárquicas da sociedade brasileira, assim como em outros momentos igualmente ritualizados, como o carnaval e as chamadas "religiões afro-brasileiras". Estes três elementos têm sido objeto de apropriações ideológicas diversas, no sentido de compor uma "identidade nacional", na qual o futebol desempenha um importante papel, como princípio aglutinador do "povo brasileiro" na sua constituição como nação.

Normalmente, o interesse dos brasileiros pelo futebol encontra-se dividido em torno da regionalidade decorrente da torcida por diferentes clubes. Os clubes de futebol simbolizam um pertencimento social com características específicas, demandando dos torcedores uma lealdade por toda a vida ("Uma vez Flamengo, Flamengo até morrer..."). Muitas vezes, os locutores esportivos se referem à torcida de um clube como "nação" ("nação colorada", "nação rubro-negra" etc., de acordo com as cores do clube), ressaltando este sentido de 'comunidade reunida' em torno do pertencimento afetivo a um grupo, a um sentimento coletivo compartilhado, no caso, mediado 
pelo time do coração'. Cabe ressaltar que apenas uma ínfima parte da torcida de um time' tem um vínculo formal com o 'clube', na qualidade de 'sócio'. O pertencimento a uma torcida é muito mais uma questão afetiva (freqüentemente mediada na infância por relações familiares) do que uma relação institucional entre um clube e seus sócios.

Esse interesse é catalisado numa dimensão 'nacional' quando está em campo a 'seleção brasileira'. Este time de futebol especial realiza uma espécie de 'unidade nacional', por meio da superação das diferenças clubísticas em prol de um bem comum: o desempenho do 'Brasil' perante outros 'países'. Todos estes termos estão empregados no sentido metonímico que cotidianamente permeia a relação entre a 'seleção nacional' e a 'nação' ou o 'país' (seja o Brasil, seja seu adversário). Boa parte da legitimação desta apropriação simbólica provém da imprensa esportiva, particularmente importante nos períodos de Copa do Mundo. Assim, é freqüente que no discurso da crônica esportiva a 'seleção brasileira' venha a 'representar' (no sentido mais metonímico do termo) o 'povo brasileiro'. Simoni Guedes (1998:20) ressalta esta apropriação simbólica da relação entre a 'seleção brasileira' e o 'povo brasileiro' por parte da imprensa esportiva:

'Tratando-se da atuação da seleção brasileira de futebol, chega a ser impressionante o modo como se passa, sem nenhuma mediação considerável, da avaliação do time para a avaliação do povo. As vitórias da seleção nacional evidenciam a capacidade do povo brasileiro enquanto as derrotas são nada menos que denúncias de sua indigência."

De fato, em grande parte, esta ligação da cultura brasileira contemporânea com o 'esporte bretão' se deve à bem sucedida participação brasileira na Copa do Mundo, torneio de futebol entre seleções nacionais realizado a cada quatro anos, desde 1930, no qual o Brasil é o país com maior número de títulos e o único a participar de todas as edições. Eventos ocorridos em Copas do Mundo fazem parte de uma espécie de 'passado mítico' da cultura brasileira contemporânea, como a histórica derrota para o Uruguai em pleno Maracanã, na partida final da Copa de 1950. Vogel (1982) igualmente destaca esta dimensão competitiva/constituidora de identidade característica da Copa do Mundo.

Faz parte da natureza de todo jogo, o futebol inclusive, que após um começo em que os contendores encontram-se em igualdade de condições, os fatos do jogo acabem criando uma hierarquia entre os participantes, dividindo-os entre vencedores e perdedores. $O$ valor socialmente atribuído à vitória ou à derrota em um determinado jogo varia de acordo com fatores que, stricto 
sensu, não se encontram no campo de jogo, como a posição das equipes dentro de um torneio, rivalidades regionais, desejo de 'vingança' por resultados passados etc. Em uma Copa do Mundo, os participantes não são meros times de futebol, mas 'seleções nacionais', uma espécie de 'encarnação simbólica' de cada nação participante do evento. Assim, uma Copa do Mundo é muito mais do que um mero torneio de futebol: ela é uma chance de se colocar a própria nação em perspectiva comparada com o resto do mundo. Pelo menos no Brasil, a Copa é considerada o apogeu do mundo dos esportes, sendo-lhe dada mais importância social do que a própria Olimpíada: afinal de contas, quem vence a Copa é, incontestavelmente, 'o melhor do mundo'.

Cabe ressaltar que houve, a partir da Copa de 1998, uma mudança sensível na definição da realidade promovida pela imprensa esportiva a respeito da transferência de atributos da seleção brasileira para o povo brasileiro, aspecto ressaltado por Simoni Guedes. A vitória na Copa de 1994, após um longo período de 24 anos sem um título em Copas do Mundo, promoveu uma rearticulação de significados nesta relação entre a avaliação da seleção brasileira e a avaliação do povo brasileiro. A conquista do tetracampeonato mundial de futebol, isolando o Brasil de seus concorrentes no número de títulos conquistados (Alemanha e Itália têm três títulos cada), representou uma espécie de 'salvaguarda' contra a derrota. Na Copa de 1998, mesmo a derrota para a França na decisão do torneio não impediu a atribuição de significados positivos à seleção, como a 'melhor do século' ou 'campeã do século'. Um anúncio do canal de televisão a cabo SPORTV, veiculado no J ornal da Tarde da segunda-feira após a derrota traduz perfeitamente este argumento: "Tudo bem. Ninguém ainda é tetra." Mesmo com a derrota por 3 x 0 (a maior goleada já sofrida pela seleção brasileira em todas as Copas do Mundo, diga-se de passagem), ainda está "tudo bem", o Brasil continua a ser o 'melhor do mundo'.

Logo após a derrota, um VT veiculado pela Rede Globo mostrava cenas das outras campanhas vitoriosas da seleção e cenas de futebol de várzea, com a seguinte locução em off:

"Valeu, Brasil! A imagem que fica do nosso futebol é essa: afinal, somos os melhores do século. Seremos sempre o país do futebol. Bola pra frente! A Globo é mais Brasil!" (grifos meus)

Quando a locução em off fala em "imagem que fica", refere-se a uma definição da realidade, à impressão causada aos 'outros', os demais países do mundo, pelo "nosso" desempenho no campo de futebol. A incorporação metonímica do 'povo brasileiro' a seus jogadores fica evidenciada 
no uso da primeira pessoa do plural, em flexões do verbo 'ser': "somos" e "seremos".

Igualmente afirmativo quanto à perenidade de 'nosso' estatuto eterno de 'país do futebol' é o anúncio veiculado na revista IstoÉ n 1503, de 22 de julho de 1998, páginas 59-60, um anúncio institucional do 'Clube dos 13' (associação dos maiores clubes de futebol do Brasil), produzido pela agência Ammirati Puris Lintas:

"Brasileiro vive futebol 24 horas por dia. Aqui, discussão é bate-bola. Se a garota passa e se insinua, deu bola. Se o garoto chega pra conferir e ela sai fora, ele diz que deu na trave. Mas, se nem vai conferir, é bola murcha. Se alguém não fala coisa com coisa, não bate bem da bola. Se a menina tem irmão ninguém chega, tem beque na área. Se alguém é bom de papo, é craque. Quando se dá bem, tá com a bola toda, agora, se é chato, é o empata. Se alguém quer saber se alguma coisa vai dar certo, pergunta: vai dar jogo? Se a coisa não anda, fica no zero a zero. Mas, se tudo dá certo, é um golaço! Entendeu porque o Brasil é, e sempre será, o país do futebol?

Bola pra frente, Brasil.

Homenagem à seleção campeã do século."

Esta longa enumeração de expressões associadas ao futebol na linguagem cotidiana do Brasil é apresentada como a prova irrefutável da participação do futebol na cultura brasileira, a ponto de tornar-se o princípio diferenciador (definidor) do Brasil perante os outros países. Este recurso retórico permite a definição assertiva da ligação do futebol como 'o' elemento definidor do Brasil, não somente no presente, mas "para sempre". Um dado imutável: o Brasil é e sempre será o país do futebol. Não obstante, o motivo da "homenagem" é a conquista do título de 1994 que, como foi visto, isolou o Brasil de seus concorrentes imediatos, e não a presença de expressões ligadas ao futebol na linguagem cotidiana. Esta presença, inegável, apenas dá conta de que o futebol desempenha um papel importante na cultura brasileira contemporânea. Daí a tornar-se 'o' princípio da identidade brasileira, entretanto, vai uma operação ideológica, ao reduzir o enorme conjunto das expressões da língua cotidiana a uma única temática, ignorando outras expressões igualmente ricas e reveladoras da cultura brasileira.

\section{NOTAS SOBRE O DISCURSO PUBLICITÁRIO}

Em um filme italiano de 1989, "Ladrões de Sabonete", de Maurizio Nichetti, o protagonista, diretor de um filme neo-realista (paródia do clássico "Ladrões de Bicicleta", de Vittorio de Sica), se vê às 
voltas com um problema quando seu filme é veiculado na televisão: o contraste entre o mundo triste, sombrio, opressivo e preto-e-branco de seu filme e o mundo alegre, colorido, festivo e despreocupado dos comerciais veiculados no intervalo. Os sofridos personagens do filme se rebelam e decidem 'trocar de mundo', passando a viver no mundo dos anúncios. O diretor tenta dialogar com os personagens, mas não há solução: a esposa do desempregado italiano do pós-guerra vai 'morar' em um anúncio de sabão em pó, e o seu filho 'muda-se' para um anúncio de chocolate. $\mathrm{O}$ diretor interpela a mulher, dizendo que seu lugar não é ali, que ela deve voltar para o filme. Ela Ihe responde que jamais voltaria; afinal, no mundo do filme ela tinha um cotidiano de sofrimentos, lavava roupa à mão, estava sempre nublado, a casa era apertada, o marido desempregado, enquanto que no mundo do comercial estava sempre ensolarado, tudo era colorido, havia música, todos dançavam e cantavam, além de haver máquinas de lavar roupa por toda parte.

O pitoresco exemplo aponta com ironia para a característica representação da 'realidade' veiculada nos anúncios publicitários: um mundo sem conflitos, sem problemas que não sejam resolvidos imediatamente (por intermédio do produto, é claro), uma espécie de 'mundo ideal'. Mesmo no senso comum se denuncia essa representação idealizada da realidade nos anúncios, como a chamada 'mulher-margarina', característica dos anúncios deste produto, que comumente mostra uma família feliz em torno de uma farta mesa de café da manhã, todos sorridentes, bonitos e bem-humorados, especialmente a jovem e bonita mãe de família, que serve a refeição aos seus entes queridos ${ }^{6}$. Tornou-se uma espécie de chavão a 'denúncia' de que o café da manhã das pessoas 'reais' não é assim, decididamente. Muito bem: a mistificação foi desmascarada, ninguém mais se deixa 'enganar' pela publicidade e estamos conversados. Será? Acredito que a questão seja um tanto mais complexa do que isso. Não só a 'mulher-margarina' continua a freqüentar os blocos comerciais dos programas de televisão, como o investimento anual em publicidade no Brasil e no mundo está constantemente crescendo. A eficácia das estratégias de marketing (do qual a publicidade é apenas uma parte) é real, e interfere de modo ativo no mercado e na sociedade. Entretanto, considerar a publicidade somente sob o ponto de vista de seu papel de 'ferramenta mercadológica' significa eliminar toda dimensão social, cultural e simbólica presente no discurso dos anúncios. Afinal de contas, os anúncios não 'vendem' apenas produtos, mas 'estilos de vida', padrões de consumo, representações da sociedade, da família, da sedução, da paternidade, da infância etc. Mais do que isso, 'vendem' uma representação destes temas, não outra. Paralelamente à finalidade comercial explícita, vende-se ideologia, estereótipos, preconceitos, forja-se um discurso 
que colabora na construção de uma versão hegemônica da 'realidade', legitimando uma dada configuração de forças no interior da sociedade. Mesmo que represente a realidade como um 'melhor dos mundos', e mesmo que ninguém aparente 'acreditar' nele, o discurso da publicidade é dotado de inquestionável eficácia simbólica.

Baudrillard (1973:176-177), neste sentido, afirma que a publicidade opera segundo a "lógica do Papai Noel". Segundo este autor, as pessoas têm para com o discurso publicitário a mesma relação que as crianças têm para com Papai Noel: não acreditam, entretanto conservam sua crença. O consumidor...

"...não 'acredita' na publicidade mais do que a criança no Papai Noel. O que não o impede de aderir da mesma forma a uma situação infantil interiorizada e de se comportar de acordo com ela. Daí a eficácia bem real da publicidade, segundo uma lógica que, apesar de não ser a do condicionamento-reflexo, não é menos rigorosa: lógica da crença e da regressão."

Dentre os vários gêneros discursivos encontrados na mídia (jornalismo, dramaturgia etc.), um dos mais suscetíveis de representações estereotipadas é o chamado 'discurso publicitário'. O tempo e o espaço limitados dos anúncios publicitários fazem com que eles necessitem utilizar representações extremamente claras e com a menor ambigüidade possível, de modo a permitir a leitura rápida e a compreensão imediata por parte do 'público-alvo' (recorte da população a quem é destinado um dado anúncio).

Neste sentido, Anne Sauvageot (1987) compara a publicidade com a técnica de sinalização das estradas, pelo fato de ambas terem a preocupação de mandar mensagens claras ao observador em um intervalo de tempo cada vez menor. Segundo ela, a publicidade é uma das protagonistas da aceleração da visualidade contemporânea, e a colaboração em sinergia da publicidade e da televisão colaborou para estabelecer esta velocidade nos ritmos sociais. Ao longo dos anos, as mensagens publicitárias vêm traduzindo/criando esta temporalidade visual que caracteriza nosso tempo. Ela cita o trabalho de J -P. Rouch, que analisa o desenvolvimento da retórica publicitária na televisão, dos anos 60 até hoje. Nos anos 60 , o número de planos de um comercial de 28 " não era maior do que seis. Em 1980, um comercial de 49 "90 contabilizou 55 planos. A duração média dos planos passou de 4"7 em 1960 para 2"5 em 1970 e para 0"9 em 1980. Esta aceleração vertiginosa da montagem dos comerciais, segundo Sauvageot (1987:179), "não somente sustenta o sentido, mas 
que a mensagem solicita". Não há lugar nem tempo para a ambigüidade no reino dos anúncios publicitários.

Assim, o 'mundo' dos anúncios é um mundo aparentemente sem conflitos, uma espécie de 'melhor dos mundos', uma representação do que se acredita ser o 'desejo' do 'público-alvo'. Erving Goffman (1987:26) refere-se a esta espécie de 'idealização visual' realizada pela publicidade:

"...publicitários esmagadoramente escolhem tipificações positivas e aprovadas (talvez para que seu produto seja associado a um bom mundo, opondo-se a ser dissociado de um mau mundo), de modo que o que vemos são caracteres idealizados usando facilidades ideais para realizar fins ideais enquanto, é claro, microecologicamente arranjado para indicar relacionamentos ideais."

Este caráter de representação de um 'mundo ideal' tem rendido para o discurso publicitário diferentes acusações: desde ser um "cadáver que sorri", como afirma Toscani (1997), até a máxima de Adorno e Horkheimer (s/d), de ser "inimiga do gênero humano", é comum ouvir dizer que a publicidade 'aliena as massas', manipula mentes, condiciona comportamentos etc. De fato, a busca da 'persuasão' do público faz parte do discurso publicitário, definido por Lagneau (1981) como sendo a defesa pública de um interesse privado. Entretanto, essas posições acusatórias devem ser um pouco relativizadas: nem o publicitário é um monstro manipulador de mentes, nem o consumidor (a rigor, todos nós) um fantoche que consome qualquer coisa que lhe digam. Na verdade, todos os participantes do processo de comunicação publicitária estão inseridos em um determinado contexto social, que a todos engloba.

Em busca de despertar no 'público-alvo' o chamado 'desejo de compra', o publicitário procura decifrar, no contexto de cada grupo social, o apelo que o levaria a consumir o produto que ele pretende vender. Para isso, ele constrói uma representação desse grupo. No discurso publicitário, essa representação transparece sob a forma de uma imagem, em que se evidencia um sistema de valores e comportamentos socialmente atribuídos pelo publicitário ao grupo em questão. Neste sentido, Charaudeau (1983:118) considera a "fala publicitária" como um gênero discursivo próprio, com características que Ihe são peculiares. Para ele, o "contrato de fala" que define o gênero publicitário realiza um duplo movimento: ocultação do circuito sócio-econômico e sedução/ persuasão do destinatário. Para tanto, o publicitário constrói uma imagem de sujeito destinatário que, sedutora/persuasiva, possibilite a identificação do destinatário tornado consumidor e justifique o consumo, num processo que ele denomina "do fazer-crer ao dever-fazer". 
Hoje em dia, a publicidade tem cada vez mais abandonado a tendência de usar apelos de cunho racionalizante, em prol de representações mais simbólicas, visando antes obter a identificação que o convencimento, ou, nos termos de Sauvageot (1987:26), "abandonando mais e mais seu papel de informação em prol de sua função de sonho".

Além disso, a técnica de produção publicitária atual tende a utilizar um número cada vez maior de profissionais para uma mesma peça, e que trabalham de modo cada vez mais autônomo, devido à chamada terceirização' no processo produtivo. Assim, o resultado final de uma peça publicitária, muito mais do que um trabalho 'em grupo', é um trabalho feito 'por um grupo' relativamente disperso, que poderia ser chamado de 'mercado de criação e produção publicitária'. Acentuo este aspecto de criação 'por um grupo' porque o somatório do trabalho destes profissionais dirigindose ao somatório dos 'públicos-alvo', a partir de representações sociais de cada um destes segmentos, forma uma espécie de 'quadro simbólico' da sociedade no interior da qual estas representações foram geradas ${ }^{7}$. Marshall Sahlins (1979:200), ao estudar a sociedade capitalista ocidental, considera as mercadorias manufaturadas como objetos reveladores de muitos aspectos da cultura desta sociedade. O conjunto obtido pela reunião desses produtos industriais seria, segundo ele, capaz de "cobrir toda a ordem cultural de uma sociedade que, ao mesmo tempo, vestiria e investiria".

Como ressalta Canevacci (1990), por conta deste processo contínuo de representação do corpo social, a retórica das imagens publicitárias muitas vezes se refere, sintetiza ou até mesmo antecipa diversas tendências culturais e comportamentais da sociedade a que pertence. Cabe notar que o discurso publicitário não é, entretanto, uma mera crônica de costumes contemporânea. Ele está carregado de conteúdo ideológico e, na medida em que defende publicamente um interesse privado, defende também uma ideologia da permanência da estrutura hierárquica da sociedade e do modo de produção capitalista que esse interesse representa, conforme aponta Everardo Rocha (1985). O universo das imagens publicitárias, assim, pode ser uma janela reveladora que se abre sobre uma espécie de "mundo das idéias" (parafraseando Platão), ou, quem sabe, um "melhor dos mundos" como talvez acreditaria o Cândido de Voltaire, construído com um somatório de símbolos dos desejos da sociedade que o engendrou.

O mercado de criação e produção publicitária, na defesa do interesse privado dos produtores das mercadorias, aproveita qualquer evento socialmente favorável ao incremento no consumo dos produtos, como o 'dia da criança' ou o 'dia dos pais', veiculando representações acerca da paternidade, da infância etc., de modo a vender gravatas ou brinquedos, conforme a ocasião. Assim, um evento 
com a importância social da Copa do Mundo para os brasileiros não poderia passar ileso por essa manipulação de sentido operada pela publicidade. A diferença é que, nesse caso, o que se representa nas imagens publicitárias é o 'ser brasileiro', nossa própria identidade nacional, transfigurada nas imagens publicitárias, mostrando à sociedade a representação de um ideal da 'brasilidade' triunfante.

\section{METODOLOGIA}

Metodologicamente, o que este trabalho busca realizar é uma interpretação do fenômeno analisado, ou seja, as representações do Brasil e dos brasileiros veiculadas nos anúncios publicitários do período da Copa do Mundo.

Para construir esta interpretação, analiso os anúncios qualitativamente, isto é, contextualizando-os ao veículo e ao momento social de sua veiculação e interpretando os diferentes significados das representações neles presentes, sem levar em conta a freqüência das veiculações nem o espaço que cada anúncio ocupou no veículo empregado, de modo a compor um painel abrangente e complexo do que foi usado como representação neste período e de como estas representações se articulam com significados referentes ao 'ser brasileiro', deixando de lado o quanto cada representação foi veiculada.

A partir da hipótese de que no período da Copa do Mundo os anúncios publicitários veiculam representações da nacionalidade, foram coletados anúncios desde 14 de março até 20 de julho de 1998, sendo que a Copa do Mundo propriamente dita ocorreu entre 10 de junho e 12 de julho daquele ano. A antecedência à data de início da Copa se justifica devido ao fato de que, à medida em que o evento se aproxima, começam a surgir 'notícias' referentes à Copa nos diferentes veículos de comunicação, tais como a reunião do grupo de jogadores da seleção brasileira, a rotina dos treinos, os últimos amistosos no Brasil antes da Copa, reportagens sobre o país-sede da competição, e mesmo notícias auto-referentes, como detalhes da estrutura de pessoal e equipamento utilizada por jornais e emissoras de TV para cobrir o evento. J untamente com estas 'notícias', começam a ser veiculados anúncios referentes à Copa que se aproxima. Tal antecedência ao evento pode ser explicada pela periodicidade da Copa, a cada quatro anos, um tempo enorme para veículos que contam o tempo em segundos. Da mesma forma, o período após o evento também é significativo para a coleta de anúncios que comentam o desfecho da competição e a 
volta dos jogadores, em uma espécie de 'volta à normalidade', tanto na imprensa quanto na publicidade. Como na partida final o Brasil foi derrotado, pouco depois de uma semana o tema foi encerrado na mídia. Se tivesse vencido, provavelmente teria sido explorado por um pouco mais de tempo.

Cabe ressaltar que no período considerado, a temática relacionada à Copa do Mundo é freqüente na publicidade, mas não absoluta. De fato, no período da competição, vários anúncios veiculam representações da nacionalidade, mas não todos. A freqüência de anúncios com temática relacionada à Copa vai aumentando com a proximidade do evento, mas mesmo nos dias em que a seleção brasileira jogou, os anúncios tematizando a participação do Brasil na competição em curso constituem a maioria, mas não chegam ao total dos anúncios. Ou seja, além do recorte do período, foi considerado um outro recorte, de ordem temática. Foram selecionados nesse período os anúncios que de alguma maneira contivessem alusão à participação do Brasil na Copa do Mundo, seja através de elementos gráficos (bolas, bandeiras, cores verde e amarela etc.), de imagens ou personagens relacionadas às atividades de 'jogar futebol' ou 'torcer' ou ainda referências verbais em textos escritos, locuções em off ou falas de personagens.

Um terceiro recorte consistiu na escolha dos veículos adequados para a coleta dos anúncios. Devido à impossibilidade de privilegiar toda a mídia, optei por uma cobertura mais intensa de basicamente três tipos de veículo: jornais, revistas e televisão. Anúncios de rádio foram levados em conta apenas circunstancialmente, devido principalmente à dificuldade de realizar registros sistemáticos, além do caráter eminentemente local dessa mídia e da multiplicidade de emissoras. Fotografei também outdoors em Campinas, Rio de J aneiro e São Paulo, e os incorporei ao banco de dados.

Um ponto de vista epistemológico que defendo neste trabalho é a atribuição de um estatuto idêntico a cada anúncio catalogado no banco de dados, a despeito do veículo, espaço no veículo, produto ou anunciante. Procuro, desta maneira, 'homogeneizar' sob a categoria 'anúncio' peças publicitárias diferentes, como anúncios gráficos e de vídeo, de modo a evidenciar padrões de representações sociais presentes nos anúncios, problemática-chave desta pesquisa. Evidentemente, os anúncios têm diferenças estruturais entre si, pela própria natureza dos veículos. Vídeos tendem a ter uma maior possibilidade narrativa, enquanto anúncios gráficos tendem a ser mais descritivos. Não obstante, pode ocorrer o inverso; assim, faço a opção metodológica de conferir um estatuto igualitário a cada anúncio, de modo a conseguir, para além das diferenças formais ou exteriores ao anúncio, ressaltar analiticamente as recorrências no que se refere a representações sociais. 
posição de Goffman (1987:27), segundo a qual os anúncios publicitários realizam uma "representação" (nos sentidos já vistos, mas especialmente no sentido de "dramatização") de cenas consideradas "cotidianas", na qual se constrói uma espécie de "hiperritualização" dessa vida cotidiana. A aproximação do anúncio com a noção de ritual deve-se à semelhança estrutural entre ambos. Segundo Goffman, tanto o ritual quanto o anúncio publicitário devem ser absolutamente "legíveis" naquilo que enunciam, a ambigüidade é prejudicial ao desempenho de ambos; da mesma forma, ambos recorrem a tipificações socialmente aprovadas e a uma gestualidade que se refere àquilo que deve ser tomado como uma resposta interior. Considerando que tudo o que pode ser visto em um anúncio é previamente determinado e escolhido, existe uma intencionalidade presente em cada elemento representado, desde os mais evidentes, como o posicionamento da câmara (fotográfica ou de vídeo), a fala, o posicionamento ou a gesticulação de um personagem, até os objetos e as cores escolhidas para 'compor' o ambiente onde a cena se passa. Desta forma, a metodologia de análise dos anúncios aqui empregada buscará encontrar nas 'representações' (dramatúrgicas e culturais) presentes nos anúncios, elementos temáticos recorrentes, de modo a configurar 'padrões' analíticos definidos.

Assim, para analisar os anúncios, parto de características gerais, exteriores ao anúncio em si, e características que chamarei de temáticas', que servirão para elaborar as categorias de análise. As características gerais individualizam cada anúncio no banco de dados, sendo compostas pelo código de identificação, dados da veiculação (veículo, duração/dimensão, localização no veículo) data da veiculação, agência criadora e produto anunciado. As características temáticas' incluem a transcrição do texto do anúncio e a sua descrição.

A descrição do anúncio é o ponto inicial do trabalho de análise. Geert (1978:17) designa o texto etnográfico como "descrição densa", em oposição à "descrição superficial", na qual apenas se descrevem os "fatos". Na descrição densa, o antropólogo constrói sua análise a partir da interpretação das diferentes "estruturas de significação" presentes no contexto discursivo analisado (no caso de Geertz, o relato do informante sobre 'sua' cultura), construindo uma "interpretação da interpretação", que vai além do plano simplesmente informativo. Uma prática descritiva que já é, em si, um ato de interpretação.

Um aporte teórico que se relaciona com a noção de "descrição densa" é a abordagem de Roland Barthes (1989: 133-138) sobre a análise do sistema semiológico que ele denomina de "mito". A noção de "mito" para Barthes é criada a partir de um paradigma semiológico: o "mito", nesta 
acepção, é um sistema semiológico de segunda ordem, um "segundo plano de significação", que toma como significante o resultado de uma outra relação semiológica, um outro signo, com o qual se relaciona de uma maneira metalingüística, num circuito de apresentação/ocultamento através do qual se realiza a operação ideológica por excelência: fazer construções da cultura passarem por dados da natureza.

No sentido de Barthes, os anúncios publicitários são veiculadores de "mitos", que podem ser 'decifrados' pela modalidade de leitura empregada. Assim como, para Geert, o antropólogo deve "interpretar a interpretação", ou seja, "ler" as metassignificações da cultura que está estudando através do discurso do informante, da mesma maneira o "mitólogo", para Barthes, deve "ler" o mito através do processo metalingüístico que o constitui, isolando o sentido construído da forma empregada para veiculá-lo, evidenciando as analogias que relacionam o sentido à forma, "desmistificando" a ambigüidade própria desse sistema semiológico particular.

Buscando realizar uma "descrição densa" dos anúncios coletados, uma espécie de 'etnografia do mundo do anúncio', com o fim de evidenciar as representações sociais neles contidas, ressalto algumas categorias ali presentes, na cena dramatizada/"mitificada" no anúncio. Dessa forma, ao analisar um anúncio, procuro evidenciar nele alguns aspectos estruturais da narrativa proposta nesse anúncio: em primeiro lugar, uma questão discursiva, acerca da natureza do enunciador: se o anúncio 'fala' alguma coisa, 'quem' fala e de que lugar? Em seguida, quando o sentido narrativo é mais evidente, busco apreender o enredo, no caso de muitos anúncios de vídeo e vários anúncios gráficos. Observo os papéis desempenhados pelos diferentes personagens em cena, através de sua atuação, posicionamento relativo em cena, falas (ou não), figurinos, tipos físicos e padrões de interação com os demais personagens ou elementos cenográficos. $\mathrm{O}$ ambiente no qual se passa o anúncio diz muito sobre os personagens que ali interagem, bem como a iconografia utilizada (o conjunto dos elementos presentes à cena). O posicionamento da câmara (fotográfica ou de vídeo), seu enquadramento e profundidade de campo, bem como a iluminação utilizados são aspectos em princípio técnicos, mas que desempenham um importante papel na construção discursiva do anúncio. Mesmo anúncios alltype (que usam apenas caracteres gráficos, como letras e números) são passíveis de veicular representações sociais, através de metáforas, metonímias ou outras figuras de linguagem. Outro aspecto observado e descrito (no caso dos VTs) é a utilização do som. Além da música, a sonorização de um anúncio de vídeo inclui ruídos de ambiência com finalidade narrativa e também ruídos em off, que caracterizam uma 'presença ausente'. Ausente visualmente, 
mas presente na narrativa. $O$ dado mais evidente de intencionalidade no anúncio é sem dúvida o uso da linguagem verbal. Seja através das 'falas' dos personagens e locuções em off, nos anúncios em vídeo, ou do texto escrito em um anúncio gráfico, a leitura direta do anúncio sempre aponta para o verbal que, evidentemente, deve ser levado em conta, não apenas por manifestar o conteúdo expresso do anúncio, sua intenção mais evidente, mas pelo que se pode depreender das frases, como pressupostos à sua enunciação. Assim, através da análise dessas instâncias discursivas presentes no processo de produção dos anúncios, busco evidenciar as representações sociais difusas ou pressupostas nestes anúncios, ressaltando o "segundo plano de significação", onde, muito adiante do plano onde meramente se vendem produtos, se 'naturalizam' ideologicamente relações de poder socialmente construídas.

Após a construção dessa "descrição densa", chego à fase de elaboração dos 'descritores'. Por esse termo, entendo o conjunto de 'chaves analíticas' que se referem a elementos e temáticas presentes em cada anúncio, o resultado conciso do trabalho de descrição interpretativa, na forma de 'palavraschave'. Em princípio, não há limites para o número de descritores associados a um único anúncio, conforme ele se relacione a diferentes temáticas. Por meio de um sistema de busca por referência cruzada, podem ser relacionados diferentes anúncios que tratam de temáticas similares, de modo a constituir recorrências de temas.

Um grupo de anúncios recorrentes quanto a um dado descritor configura um padrão temático, com evidentes variações no conjunto dos anúncios. Reunidos por um mesmo descritor a eles associado, cada anúncio manipula elementos discursivos (texto verbal, enredo, personagens, iconografia...) com relação a um mesmo aspecto, evidenciado pelo descritor, de modo a estabelecer recorrências na abordagem de temas, como por exemplo, relações de gênero ou relações raciais. A partir desses elementos recorrentes, podem ser estabelecidos padrões de representação das temáticas dramatizadas, de modo a possibilitar a construção de uma interpretação acerca da maneira e das categorias segundo as quais o 'ser brasileiro' é representado pelo discurso publicitário no período da Copa do Mundo.

\section{UMA APUCAÇÃO ANAĹTICA: A REPRESENTAÇÃO DOJ OGO DURANTE A COPA}

Uma visão geral dos anúncios coletados evidencia alguns temas muito recorrentes, que não apenas 
perpassam a publicidade, mas que chegam a configurar uma espécie de 'padrão temático' na mídia em geral durante o período da Copa do Mundo. Durante o período do Natal, por exemplo, a temática em voga na mídia trata da confraternização em família, com a troca de dádivas (os presentes) simbolizando o fortalecimento das alianças e a integração no plano familiar. Estes temas referem-se sob o viés do mercado, evidentemente - a tradições e elementos rituais existentes na sociedade, buscando a pertinência com o período ritual socialmente vivido. O período da Copa do Mundo também passa por um processo de 'ritualização mediatizada' similar, porém a partir da temática-chave do 'jogo'. Pode-se dizer que o tempo da Copa do Mundo no Brasil é um tempo para jogar'. Um tempo em que se celebra o prazer do jogo, tanto do jogo de futebol, quanto do sorteio, da fantasia e da embriaguez, assemelhando-se de uma certa forma ao carnaval, mas com uma ênfase maior no aspecto competitivo: se no carnaval carioca, por exemplo, a competição ocorre 'entre' as escolas de samba, definindo o pertencimento dos participantes a comunidades eminentemente locais (Magueira, Estácio, Vila Isabel etc.), na Copa do Mundo, a competição ocorre 'contra' os 'outros', os 'estrangeiros', o que promove um sentimento coletivo de pertencimento nacional, pela via do jogo.

Um referencial teórico interessante para entender a representação da sociedade brasileira pela publicidade durante a Copa do Mundo pode ser buscado na obra Os J ogos e os Homens, de Roger Caillois (1990). Pondo à parte o acento evolucionista que ele dá a algumas de suas interpretações do jogo em sociedades "primitivas" e "civilizadas", a divisão do jogo em categorias elaborada por ele permite um aporte teórico bastante apropriado neste sentido. Em sua análise, Caillois classifica os jogos em quatro categorias básicas: agôn, os jogos de competição; alea, os jogos de azar; mimicry, os jogos de representação e ilinx, os jogos de vertigem.

O grande evento ritualizado que determina a construção deste 'tempo lúdico' no Brasil, a Copa do Mundo de futebol, fornece a linha-mestra das representações do 'jogo' na sociedade brasileira pela publicidade. Elementos gráficos ou temáticos do jogo de futebol encontram-se presentes na maioria absoluta dos anúncios coletados, seja mostrando jogadores em ação, designando os consumidores potenciais como 'torcida', apresentando o verbo 'escolher' trocado por 'convocar', ou mesmo trocando graficamente as letras ' $O$ ' por bolas de futebol, associa-se o futebol à vida cotidiana representada no mundo dos anúncios. Uma representação gráfica muito freqüente em anúncios de jornal consiste em uma espécie de 'metáfora visual', na qual o círculo da bandeira brasileira é trocado por uma bola de futebol, ou então, simplesmente justapondo uma bola de futebol à bandeira brasileira, quase um 'emblema' destes anúncios, representação gráfica 
do 'país do futebol', no qual bandeira e bola se equivalem como símbolos pátrios. A apresentação do jogo como 'metáfora da realidade' pelos anúncios instaura uma dimensão futebolística na vida cotidiana, um 'modo lúdico', associado ao 'ser brasileiro'. Em um anúncio da cerveja Kaiser, os freqüentadores fazem da tampinha da cerveja uma bola, que dominam e passam com maestria, até fazer um 'gol', chutando-a por uma janela. É claro, o 'gol' é motivo de comemoração de todos no bar (e de beber outra cerveja). A prática do 'controle de bola' (popularmente conhecida como 'embaixada') é outra maneira pela qual a publicidade representa com freqüência a habilidade com a bola, vista como um valor. Acentuo o aspecto de 'valor' a esta prática, porque é comum ver nos anúncios os garotos-propaganda e os gimmicks (personagens, em geral em desenho, animados ou não, que funcionam como 'símbolos' de uma determinada marca) demonstrando grande controle da bola, fazendo embaixadas sem fim, associando-se, por esta via, ao valor absoluto concedido ao futebol brasileiro neste período. Da mesma maneira, o motivo do gol é representado com freqüência. Manifestação do poder de um time, fator que determina a vitória e a derrota dentro de campo, o gol é constantemente representado nos anúncios. Assim como o controle da bola, freqüentemente o gol é feito pelo garoto-propaganda ou gimmick, associando o valor do gol ao produto em questão.

Um aspecto que complementa a ludicidade associada ao futebol durante o período da Copa do Mundo é a enorme quantidade de promoções de venda sob a forma de sorteios. Sorteia-se de tudo, desde automóveis (o VW 'Gol' é o mais sorteado, por razões óbvias) e viagens à França para assistir a Copa até brindes simples, como bolas, bonés ou camisetas.

Uma novidade neste campo surgida por ocasião da Copa de 1998 foi a entrada em cena dos sorteios realizados por telefone, desvinculados de qualquer promoção de venda (em uma promoção normal, certo valor em compras dá direito a um cupom que pode ser sorteado). Todas as emissoras de televisão montaram o seu plano de tele-sorteios pelo sistema conhecido como '0-900'. Cada telefonema para o número estipulado corresponde a um certo valor, debitado na conta telefônica. Antes dos jogos, durante o intervalo e logo após o seu término, apresentadores entravam em cena para sortear prêmios diversos, de automóveis e casas mobiliadas a prêmios em dinheiro. A Rede Globo criou o sorteio "500 Gols do Faustão", sorteando mais de 500 automóveis, com a apresentação de Fausto Silva e Cissa Guimarães. A Rede Manchete criou o "Bolão do Zagallo", em que, além do prefixo, o torcedor-jogador discava um palpite para acertar o resultado de um dado jogo. $\mathrm{O}$ 'cassino telefônico' em que se transformou a televisão brasileira foi considerado ilegal e tentativas judiciais de interromper os sorteios foram infrutíferas. As emissoras se recusaram a receber as liminares, recorreram 
na justiça, retardaram o processo o tanto que puderam e a Copa terminou com os sorteios acontecendo a todo vapor, sem que nenhuma conseqüência tenha ocorrido, salvo, é claro, o extraordinário lucro obtido pelas emissoras.

Acredito que, tanto no que diz respeito às promoções de vendas realizadas à base de sorteios quanto nos sorteios telefônicos realizados pelas emissoras de televisão, está presente um mesmo motivo: a possibilidade de cada torcedor 'participar do jogo'. Em um processo que pode ser chamado de 'reflexivo', existe uma demanda social pela participação na emoção do jogo, atendida pelos sorteios. Os sorteios, por sua vez, estimulam a participação no jogo, ampliando a demanda, e assim sucessivamente, colaborando para configurar a lógica lúdica deste período. Torcer é diferente de jogar. O jogo implica uma participação ativa por parte do jogador - mesmo que seja apenas dar um telefonema - enquanto a 'torcida' é feita basicamente de angústia impotente. A tentativa de 'fazer alguma coisa' é às vezes resolvida no campo da magia e da religião, tema de que tratarei mais adiante. Outra forma de 'participação ativa' é 'concorrer' aos prêmios sorteados. Basta ter sorte, um atributo tão intangível que qualquer um pode possuir. Ou não.

A Copa do Mundo, além de várias maneiras de jogar futebol, também coloca em contato variações sobre outros aspectos relacionados a este esporte, especialmente no que se relaciona às maneiras de torcer. Efeitos como a 'ola' (em que o movimento sincronizado dos braços dos torcedores faz uma 'onda' que varre as arquibancadas) foram popularizados em Copas do Mundo, assim como a pintura de rostos dos torcedores com as cores nacionais, freqüentemente focalizados em detalhe nas transmissões dos jogos. Torcedores de todas as partes do mundo incorporaram a nova prática e, em 1998, as arquibancadas foram cobertas por rostos pintados com as mais diversas cores e motivos. A publicidade também incorporou a novidade: o valor simbólico de um rosto pintado é evidente. O rosto pintado remete à sociedade tribal, matriz simbólica da idéia de 'nação'. Além das enormes possibilidades estéticas do uso do rosto humano como tela, um rosto pintado deixa de ser um rosto, torna-se máscara. Símbolo dos mais antigos, presente nas mais diversas culturas, a máscara simboliza/realiza a investidura em um outro papel. O mascarado deixa de ser indivíduo, passa a ser o 'outro', o 'representado', seja uma divindade, um palhaço, um super-herói, um personagem teatral ou uma nação, o mascarado diferencia-se de quem está por trás da máscara. Assim, uma pessoa vestida de verde-amarelo, com o rosto pintado de verde-amarelo personifica de modo inequívoco o torcedor brasileiro'. Como já foi visto, o pouco tempo e espaço disponíveis 140 para os anúncios publicitários fazem com que eles evitem a ambigüidade. Quanto mais facilmente 
compreensíveis os signos empregados em um anúncio, tanto melhor. Diversos anúncios exploram o potencial gráfico e simbólico dos rostos pintados e das roupas verde-amarelas, 'fantasias' de jogadores da seleção, tornando o mundo dos anúncios na Copa um grande baile de máscaras, uma espécie de 'festa à fantasia' em que todos se 'fantasiam' de brasileiros.

$\mathrm{O}$ rosto pintado evidencia de modo inequívoco o pertencimento à nação na qualidade de 'torcedor', mas mesmo sem o rosto pintado, apenas com a camiseta da seleção brasileira vestida pelos torcedores nos anúncios (e fora deles) - incorporadas ao ritual 'jogo do Brasil' - já está representada a investidura de um 'papel', configurando o padrão típico do jogo de tipo mimicry: 'brincar' de 'ser outro', dotar o mundo de outro sentido, criar um mundo diferente. Uma meta-representação, o 'mundo do futebol' representado pelo 'mundo dos anúncios'.

Os jogos do tipo ilinx, associados à vertigem e ao estar 'fora de si', estão representados na publicidade da Copa do Mundo basicamente em dois momentos: pelo incentivo ao consumo de bebidas alcoólicas, mesmo em anúncios de outros produtos, e pela representação do êxtase provocado pelo 'gol do Brasil'.

O ritual 'jogo do Brasil' está associado a determinados padrões de consumo. Entre eles, destaca-se o consumo de bebidas alcoólicas, especialmente cerveja, embora o consumo de outras bebidas alcoólicas também seja referido nos anúncios. A embriaguez alcoólica é freqüentemente associada a uma maneira de 'comemorar' um evento socialmente favorável, como parte de um 'ritual de passagem dionisíaco', no qual se festeja uma conquista, seja uma formatura, um casamento ou a conquista de um campeonato de futebol. Nos anúncios publicitários, é comum se ver os 'torcedores' com olhar angustiado ou entusiasmado em direção a um televisor, segurando com a mão um copo de bebida alcoólica, ou brindando (outro ritual associado ao consumo de bebidas alcoólicas), tendo ao fundo uma festa com bandeiras nacionais.

Outro momento gerador de 'êxtase', representado com freqüência nos anúncios é o momento do 'gol do Brasil'. Momento máximo do jogo de futebol, afirmação inequívoca da capacidade de um time, etapa da vitória, humilhação do adversário, tudo a um só tempo: um gol da seleção brasileira em uma Copa do Mundo representa, para os brasileiros, uma espécie de "fato social total". O valor simbólico deste momento fugaz é apropriado com freqüência pela publicidade, investindo seus produtos das mesmas conotações positivas representadas pelo 'gol do Brasil'. Assim, representam-se torcedores em 'êxtase', pulando, abraçando-se, dançando, manifestando 'a liberdade e a espontaneidade' característicos do êxtase dionisíaco, a libertação das peias morais, 
civis e religiosas. A comemoração do 'gol do Brasil' suscita a vivência do êxtase, que a publicidade, representando, produz e reproduz.

\section{PARA TERMINAR}

Diversas outras dimensões da sociedade brasileira, representadas nos anúncios do período da Copa do Mundo, foram analisadas na tese de doutoramento e, infelizmente, não puderam ser adequadamente desenvolvidas neste espaço, como representações de papéis de gênero, de composição racial, de classe social, da nacionalidade e da religião. Entretanto, acredito que este ensaio permita que se suscitem alguns questionamentos acerca do papel desempenhado pela publicidade como colaboradora ativa na produção e reprodução de imaginários sociais, que vão se refletir, em última análise, na manutenção de uma dada relação de forças entre os diversos grupos no interior da sociedade. Acredito que seja interessante ressaltar, igualmente, a possibilidade de pesquisa antropológica sobre um objeto relativamente pouco explorado por esta disciplina: os produtos dos meios de comunicação de massa, os chamados 'bens culturais'. Como ressalta Carmen Rial (1999), os trabalhos antropológicos nesta área usualmente derivam para os estudos da recepção, analisando etnograficamente o impacto da comunicação de massa nas comunidades pesquisadas. Espero com este trabalho ajudar a expandir o campo da pesquisa antropológica também sobre o outro lado do processo: a produção e veiculação de representações sobre a sociedade, 'desnaturalizando' o que parece 'evidente' e 'dado', única forma de superar a ditadura do consenso.

Édison Luis Gastaldo, mestre em Antropologia Social (UFRGS) e Doutor em Multimeios (Unicamp), éprofessor assistente do Centro de Ciências da Comunicação daUnisinose professor-visitantena University of M anchester (Inglaterra). 


\section{NOTAS}

1 Entendo o termo "ímagem" no sentido mais amplo defendido por J oly, como "signo analógico", o que compreende uma ampla gama de representações, desde imagens verbais até as imagens fotográficas ou fílmicas. (Ver J OLY, 1994)

2 No Rio de J aneiro, muitos dos maiores e mais "populares" clubes de futebol começaram em fins do século XIX como clubes de remo para a elite carioca de então, como o "Clube de Regatas Flamengo" ou o "Clube de Regatas Vasco da Gama". Sobre a história dos clubes de futebol no Rio de J aneiro, ver MATTOS, 1998.

3 O crédito a Charles Miller por ter supostamente trazido o futebol ao Brasil não é unânime entre os autores pesquisados. Entretanto, o "mito" de "Charles Miller e suas duas bolas" é, sem dúvida, a representação dominante sobre a origem do futebol no Brasil, principalmente no âmbito da imprensa esportiva. Ver, a este respeito, MEIHY, 1982.

4 Ver também DA MATTA, 1979.

5 Ver também, neste sentido, Da Matta e Soárez, 1999.

6 Ver, neste sentido, SIQUEIRA, 1995.

7 Atualmente, o mercado publicitário representa o pertencimento a diferentes camadas sociais a partir de aspectos quantitativos e principalmente qualitativos dos produtos consumidos, os chamados "padrões de consumo", substituindo a classificação por faixa de renda. Assim, segundo a publicidade, a categoria "consumo" vai aos poucos substituindo a categoria "produção" na configuração ideológica que ela faz da hierarquia social. 


\section{REFERÊNCIAS BIBLIOGRÁFICAS}

ADORNO, Theodor W. e HORKHEIMER, Max. s/d. "Excertos". In: VVAA, Humanismo e Comunicação de Massa (Comunicação/2). Rio de J aneiro, Tempo Brasileiro.

BARTHES, Roland. 1989. Mitologias. Rio de J aneiro: Bertrand Brasil.

BAUDRILLARD, J ean. 1973. O Sistema dos Objetos. São Paulo: Perspectiva.

BOURDIEU, Pierre. 1997. Sobre a Televisão. Rio de J aneiro: Zahar.

CAILLOIS, Roger. 1990. Os J ogos e os Homens. Lisboa: Edições Cotovia.

CANEVACCI, Massimo. 1990. Antropologia da Comunicação Visual. São Paulo, Brasiliense.

CHARAUDEAU, Patrick. 1983. Langage et Discours - Eléments de Semiolinguistique. Paris: Hachette.

DA MATTA, Roberto. 1979. Carnavais, Malandros e Heróis. Rio de J aneiro: Zahar.

. 1982. "Esporte na Sociedade: Um Ensaio sobre o Futebol Brasileiro". In: R. Da Matta (org.), Universo do Futebol. Rio de J aneiro: Pinakotheke.

DA MATTA, Roberto e SOÁREZ, Elena. 1999. Águias, Burros e Borboletas: Um Estudo Antropológico do J ogo do Bicho. Rio deJ aneiro: Rocco.

DENZIN, Norman and LINCOLN, Yvonne. 1998. The Landscape of Qualitative Research - Theories and Issues. Thousand Oaks: Sage Publishers.

GASTALDO, Édison L. 2000. A Nação e o Anúncio: A Representação do 'Brasileiro' na Publicidade da Copa do Mundo. Tese de Doutorado em Multimeios, Instituto de Artes, Unicamp, Campinas.

GEERTZ, Clifford. 1978. A Interpretação das Culturas. Rio de J aneiro: Zahar.

GOFFMAN, Erving. 1987. Gender Advertisement. New York: Harper and Row.

GUEDES, Simoni L. 1998. "O Povo Brasileiro no Campo de Futebol". In: O Brasil no Campo de Futebol. Rio de J aneiro: EDUFF.

J OLY, Martine. 1994. Introduction à L'Analyse de L'Image. Paris: Éditions Nathan.

LAGNEAU, Gérard. 1981. A Sociologia da Publicidade. São Paulo: Cultrix.

MATTOS, Cláudia. 1998. Cem Anos de Paixão. Rio de J aneiro: Rocco.

MEIHY, J osé C. (org). 1982. Futebol e Cultura: Coletânea de Estudos. São Paulo: Imprensa Oficial do Estado.

OLIVEN, Ruben G. 1986. "A Malandragem na Música Popular Brasileira". In: Violência e Cultura no Brasil. Petrópolis: Vozes.

RIAL, Carmen S. 1999. '" aponês está para a TV assim como Mulato para Cerveja: Imagens da Publicidade no Brasil". In: C. Eckert e P. Monte-Mór (orgs.), Imagem em Foco: Novas Perspectivas em Antropologia. Porto Alegre: Ed. UFRGS. 
ROCHA, Everardo P. G. 1985. Magia e Capitalismo: um Estudo Antropológico da Publicidade. São Paulo: Brasiliense.

SAHLINS, Marshall. 1979. Cultura e Razão Prática. Rio de J aneiro: Zahar.

SAUVAGEOT, Anne. 1987. Figures de la Publicité, Figures du Monde. Paris: PUF.

SIQUEIRA, F. B. G. 1995. A Mulher Margarina: Uma Representação Dominante em Comerciais de TV nos Anos 70 e 80, Dissertação de Mestrado em Multimeios, Instituto de Artes, Unicamp, Campinas.

SOARES, Antônio J . G. 1994. Futebol, Malandragem e Identidade. Vitória: SPDC/UFES.

TOSCANI, Oliviero. 1997. A Publicidade é um Cadáver que nos Sorri. São Paulo: Ediouro.

VOGEL, Arno. 1982. "O Momento Feliz: reflexões sobre o futebol e o ethos nacional". In: R. Da Matta (org.), Universo do Futebol. Rio de J aneiro: Pinakotheke. 


\section{RESUMO}

Este trabalho consiste em uma análise antropológica das representações culturais referentes ao "ser brasileiro" a partir dos anúncios publicitários veiculados no período da Copa do Mundo de 1998. A partir da abordagem antropológica de um corpus de 415 anúncios publicitários veiculados em jornais, revistas e televisão durante o período da Copa do Mundo, busco analisar as articulações de significados vinculados às representações do Brasil e dos brasileiros presentes nestes anúncios. Utilizando um paradigma antropológico hermenêutico, procuro construir uma "etnografia do mundo dos anúncios", visando a compreender a ideologia neles presente, bem como as representações da sociedade ali veiculadas, que colaboram na configuração de um tempo social especial, regido pela lógica do jogo: um tempo para jogar.

\section{ABSTRACT}

This article is an anthropological analysis of cultural representations on "being Brazilian" ("ser brasileiro") found in advertisements during 1998 World Cup. It aims to analyze the meanings related to the representation of Brazil and Brazilians found in a corpus of 415 newspapers, magazines and television ads of that period. Using the hermeneutic anthropological paradigm, it attempts to construct an "ethnography of the realm of propaganda", which aims to understand the ideology presented in these ads, as well as the representations of society they convey, which collaborates to the configuration of a special social time, ruled by the logic of the game: a time for playing. 